\title{
Geological context and origin of the mineralization of the historic and prehistoric iron mines in the Gavà area, Catalonia, NE Iberian Peninsula
}

Yael Díaz-Acha, Marc Campeny, Joan Carles Melgarejo, Josep Bosch, Saleh Lehbib, Lisard Torró, Joaquín A. Proenza, Montgarri Castillo-Oliver, Antoni Camprubí, Cristina Villanova-de-Benavent, Aleu Andreazini, Míriam Pastor, Núria Pujol-Solà, Sandra Amores, Jingyao Xu, Júlia Farré

Yael Díaz-Acha
ydiaz@bcn.cat
Marc Gampeny
Museu de Ciències Naturals de Barcelona. Parc de la Ciutadella
s/n, 08003 Barcelona, Spain.
Joan Carles Melgarejo
Joaquín A. Proenza
Aleu Andreazini
Míriam Pastor
Núria Pujol-Solà
Sandra Amores
Jingyao Xu
Júlia Farré
Departament de Mineralogia, Petrologia i Geologia Aplicada,
Facultat de Ciències de la Terra, Universitat de Barcelona. Martí
i Franquès s/n, 08028 Barcelona, Spain.

Josep Bosch

Museu de Gavà. Plaça de Dolors Clua, 13, 08850 Gavà, Barcelona, Spain.

Saleh Lehbib

Departament de Mineralogia, Petrologia i Geologia Aplicada, Facultat de Ciències de la Terra, Universitat de Barcelona. Martí i Franquès s/n, 08028 Barcelona, Spain.

Ministery of Water and the Environment, Sahrawi Arab Democratic Republic

\section{Lisard Torró}

Departament de Mineralogia, Petrologia i Geologia Aplicada, Facultat de Ciències de la Terra, Universitat de Barcelona. Martí i Franquès s/n, 08028 Barcelona, Spain.

Departament de Geologia, Facultat de Ciències, Universitat Autònoma de Barcelona. Edifici Cs, 08193 Bellaterra (Cerdanyola del Vallès), Spain.

Departamento de Ingeniería de Minas, Pontificia Universidad Católica de Perú. Avenida Universitaria 1801, San Miguel, Lima 32 , Peru.

\section{Montgarri Castillo-Oliver}

Departament de Mineralogia, Petrologia i Geologia Aplicada, Facultat de Ciències de la Terra, Universitat de Barcelona. Martí i Franquès s/n, 08028 Barcelona, Spain. ARC Centre of Excellence for Core to Crust Fluid Systems and GEMOC, Department of Earth and Planetary Sciences, Mac-quarie University.NSW 2019, Australia.

\section{Antoni Camprubí}

Instituto de Geología, Universidad Nacional Autónoma de Méx-ico. Ciudad Universitaria, 04510 Coyoacán, CDMX, Mexico.

\section{Cristina Villanova-de-Benavent}

School of Environment and Technology University of Brighton. Mithras House, Lewes Rd., Brighton BN2 4AT, United Kingdom.

BOL. SOC. GEOL. MEX. 2019

VOL. 71 NO. 2

P. $321-342$

http://dx.doi.org/10.18268/BSGM2019v7 ln2a6

Manuscript received: January 15, 2018.

\section{ABSTRACT}

Mining for iron resources in the Gavà area of Catalonia occurred intermittently during the Iberian and Roman epochs, the Middle Ages, and continuing until the industrial era as evidenced by historical and archaeological documents. Iron mining in this area could have occurred even earlier, during the Neolithic period. Iron ores were formed in two stages: $(1)$ a regional hydrothermal alteration associated with Hercynian thrusts that produced the ankeritization of limestones within the Paleozoic series, and (2) the karstic replacement of these iron-rich carbonates during the Pliocene and Quaternary by means of supergenic fluids that produced ochres with goethite and hematite. The style of mineralization largely depends on the characteristics of the replaced protolith, and three styles of mineralization can be defined: (1)The supergenic replacement of ankeritized massive Pridolian limestones only produced local replacements that were restricted to structural or stratigraphic discontinuities, therefore, the mineralization has reduced dimensions and occurs as irregular veinlets or pipes; (2) The replacement of interbedded ankeritized limestones and pyrite-bearing shales (Lockovian) produced massive ores in podshaped bodies rich in silica impurities derived from the altered shales; and (3) The replacement of carbonates overthrust by pyrite- and phosphate-rich shales favored the formation of massive stratabound deposits, which are the largest and highest grade deposits in the study area, and may be locally enriched in minerals of the alunite supergroup and $\mathrm{Ca}$ - and $\mathrm{Fe}$-rich phosphates. Outcrops of all of these styles of mineralization were mined by the Iberian cultures, during the roman period and in the Middle Ages, taking advantage of the relatively high metallurgical quality of the ores.Therefore, the exploitation during these epochs was artisanal by means of trenches or small pits. In contrast, during the industrial era only the massive stratabound deposits were exploited in open pits and underground galleries.

Keywords: iron mining, karst, supergenic, phosphates, alunite, Iberian culture.

\section{RESUMEN}

La minería de los recursos de hierro del área de Gavà (Cataluña) fue activa de forma intermitente durante las épocas Ibérica y Romana, la Edad Media, y hasta la era industrial, lo cual se ha probado mediante datos arqueológicos y documentos históricos. Es posible que, inclusive, la minería de hierro en el área hava existido durante el periodo Neolítico. Las mineralizaciones de hierro se formaron en dos estadios: (1) alteración hidrotermal regional asociada a cabalgamientos Hercínicos que produjo ankeritizaciones de calizas en las series del Paleozoico, y (2) el reemplazamiento kárstico de los carbonatos ricos en hierro durante el Plioceno y el Cuaternario por medio de fluidos supergénicos que produjeron ocres con goethita y hematites. El estilo de mineralización depende en gran medida de las características del protolito reemplazado, lo cual lleva a la definición de tres estilos de mineralización: (1) El reemplazamiento supergénico de calizas masivas ankeritizadas del Pridoliense produjo únicamente reemplazamientos locales restringidos a discontinuidades estructurales o estratigráficas por lo tanto, las mineralizaciones son de dimensiones reducidas en forma de vetillas o masas verticales irregulares; (2) El reemplazamiento de alternancias de calizas ankeritizadas con pizarras que contienen pirita diseminada (Lockoviense) produjo bolsadas de mineralizaciones masivas ricas en sílice derivadas de las pizarras alteradas; (3) El reemplazamiento de carbonatos cabalgados por pizarras ricas en sulfuros y fosfatos $\mathrm{fa}^{-}$ voreció la formación de mineralizaciones estratoligadas masivas, que son las de mayor tamaño y grado en el área de estudio, pudiendo estar localmente enriquecidas en minerales del supergrupo de la alunita y en fosfatos de $\mathrm{Ca}$ y $\mathrm{Fe}$. Afloramientos de todos estos estilos de mineralización fueron explotadas tanto en la antigüedad como en la Edad Media, aprovechando la alta calidad metalúrgica de las menas, pese a que los dos primeros estilos de mineralización presentan cuerpos de reducido tamaño. Por ello, en dichas épocas la explotación fue artesanal mediante trincheras o pocillos. En cambio, en la época industrial sólo se beneficiaron los recursos masivos del tercer estilo de mineralización a cielo abierto y a través de galerías.

Palabras clave: minería de hierro, karst, supergénico, fosfatos, alunita, cultura Íbera. 


\section{Introduction}

The Iberian culture settled along the Mediterranean coast between the southeastern part of the Iberian Peninsula and southeastern France between the sixth century $\mathrm{BC}$ and the third century AC. Many small cities and towns of this period are found along the coastal area of Catalonia (Belarte et al., 2001; Sanmartí, 2014). This period represents the Iron Agein this area, and the existence of iron mines was a key factor for the development of many settlements nearby.

Iron deposits of many different styles, such as skarns, hard grounds, and karstic deposits, are found along the Catalan Coastal Ranges (CCR) (Figure 1). Some of the iron deposits, according to archeological evidence, were mined in the Iberian towns of Les Guàrdies near El Vendrell, 60 km SW of Barcelona (Asensio et al., 1996), and Fontscalents near Castellar del Vallès, $40 \mathrm{~km} \mathrm{~N}$ of Barcelona (Coll et al., 1993). Many others were mined during the Middle Ages, like the Els Crossos mines located in a magnetite skarn deposit near Les Borges del Camp, 120 km SW of Barcelona (Jové, 1981), and during the nineteenth century, as the Fontscalents mines that were exploited again (Planas and Portolés, 1995). Among karstic deposits, those of Gavà have the best outcropping conditions, favored by intensive mining and archeological excavations. Therefore, these mines allow studying the iron deposits as a representative of the karstic iron deposits in Catalonia.

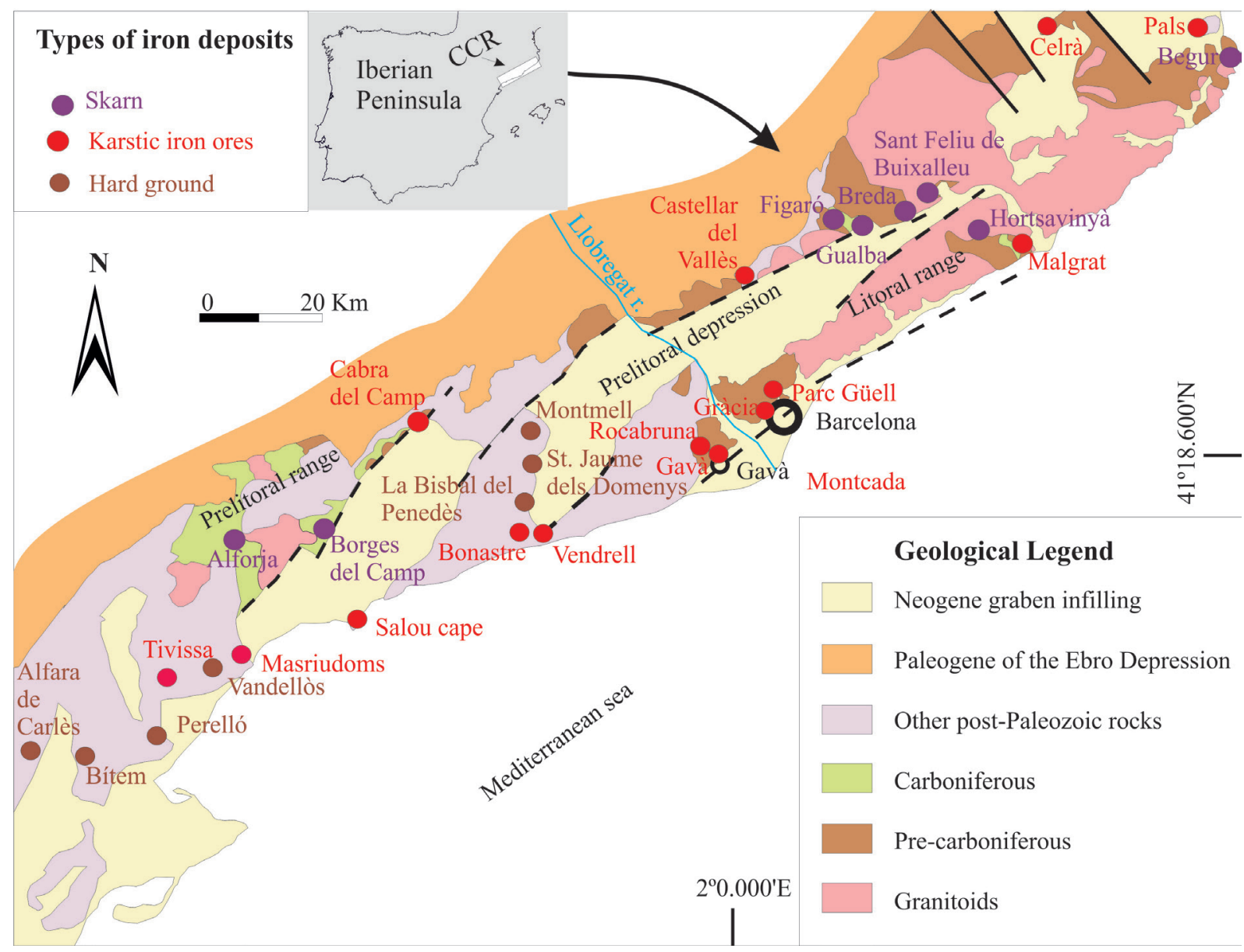


The Gavà area is famous worldwide for the existence of ancient Neolithic mines (Alonso et al., 1978; Villalba et al., 1986, 1989, 1990; Blasco et al., 1991; Camprubí et al., 1994, 2003; Costa et al., 1994; Bosch et al., 1996; Villalba, 2002; Díaz-Acha et al., 2019) and the important archeological objects found therein, such as the Gavà Venus (Bosch and Estrada, 1994) and variscite ornaments (Borrell and Estrada, 2009). However, many other types of mining operations for iron exist in the same area, in many cases in the immediate vicinity of the Neolithic works and separated from them by only tens of meters. The archeological objects, such as pottery, found inside these mines, and some absolute carbon dating, established that no less than 16 of these mines were active during the Iberian and Iberian-Roman periods (Villalba and Alonso, 1984; Burjachs et al., 1991; Molinàs, 2007; Álvarez and Estrada, 2009; Bordas et al., 2009, 2010). There are evidences of other small open-shaft operations of these iron ores, during the Middle Ages (Campmany et al., 2004) and the Modern Age (Bordas et al., 2009), but the largest mining operation on these ores was developed during the industrial era since the mid-nineteenth century (Maureta and Thos, 1881) and reworked during the early twentieth century). The last stages of mining produced open pit extractions and large galleries, as in the case of the Elvira mines in the Rocabruna range, NW Gavà (Maluquer, 1905; Bareche and Viñals, 1994). The Rocabruna mines were probably worked since antiquity. However, large-scale modern mining destroyed any evidence of earlier exploitation. There are two essential points those agree with the fact that these mines were exploited in Antiquity: the outcrops of iron ores are larger than any other known Iberian or Iberian-Roman settlement in Catalonia and, as already mentioned, mining existed in this specific area (the Les Ferreres range and the Can Tintorer complex) since the Neolithic.

The aim of this contribution is to describe the geological context of the Gavà iron ores and their ge- netic model, particularly of those iron ores found in the archeological sites, in order to understand how the Iberian and Iberian-Roman population might have used these natural resources.

\section{Geological background}

The study area is locatedin the central part of the CGR. The GCR are classically divided in two NE-SW-trending ranges (Prelittoral and Littoral) separated by the Prelittoral depression (Anadón et al., 1979). These geological units are separated by regional faults which acted as NE-SW strike-slip faults during the Alpine compressive event (Paleogene) and as normal faults during the Neogene, thus generating alternate faults and associated grabens as well as the present coastline (Anadón et al., 1985a). The study area lies in the Littoral range, where a Paleozoic metamorphic basement is unconformably overlain by Mesozoic sedimentary rocks. All of them are covered by Quaternary sediments towards the SE (Costa et al., 1994).

The iron deposits in the CGR are generally found in the Paleozoic basement. The stratigraphy of the Paleozoic basement has been studied in detail in the areas near Barcelona (Julivert and Duran, 1990a; García-López et al., 1990, 1996). The Paleozoic series starts with Late Ordovician orthoquartzites overlain by $100 \mathrm{~m}$ of interbedded black shales with cherts and alkaline volcanics of Llandoverian age, $50 \mathrm{~m}$ of black shales with interbedded thin quartzites (Wenlockian), and $50 \mathrm{~m}$ of black shales (Ludlowian). This unit is overlain by La Creu Formation which is $30-40$ m thick and it is made of Pridolian nodular limestones (Julivert et al., 1985). These limestones are conformably covered by the Olorde unit, which starts with 2-3 m of Lower Lockovian black shales overlain by an interbedding of limestones and reddish shales (Middle Lockovian) that grades to green to bluish marls with carbonate nodules (15-20 m thick, Upper Lockovian) and limestones that alternate with 


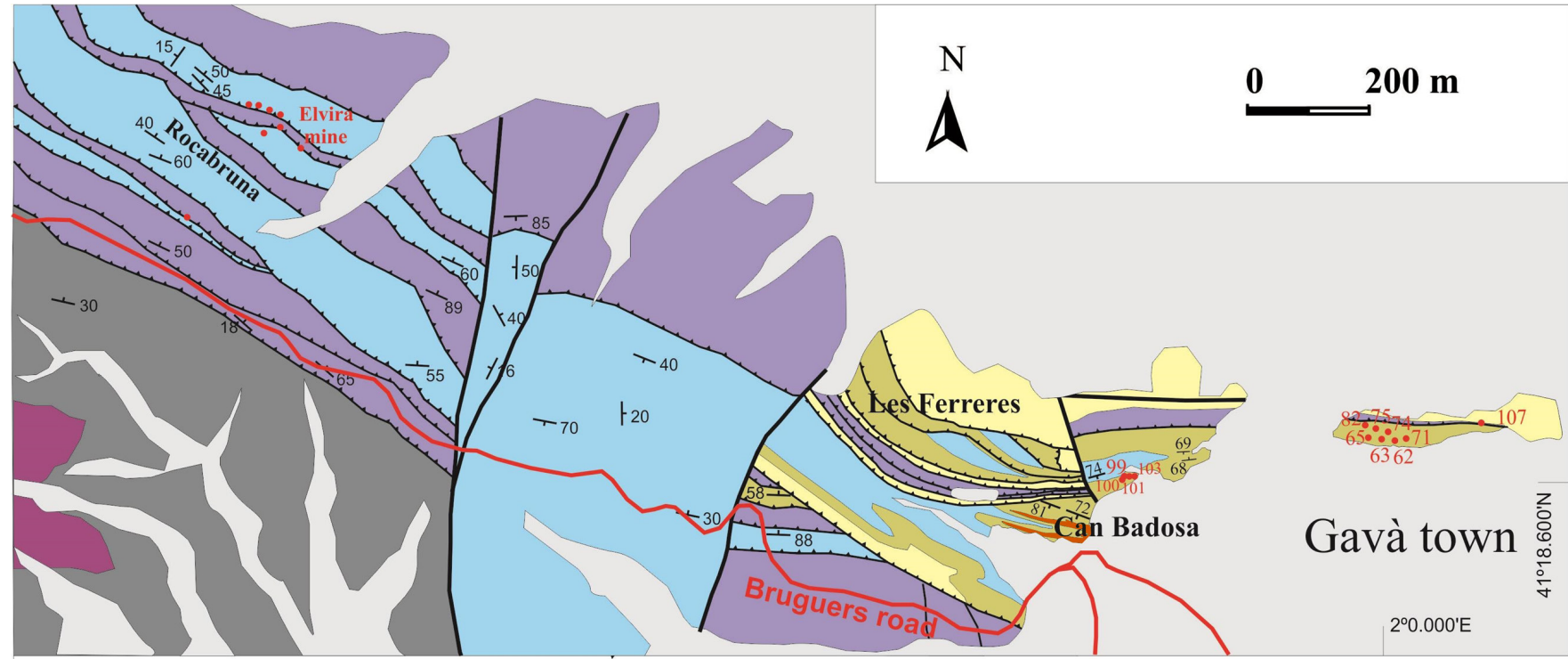

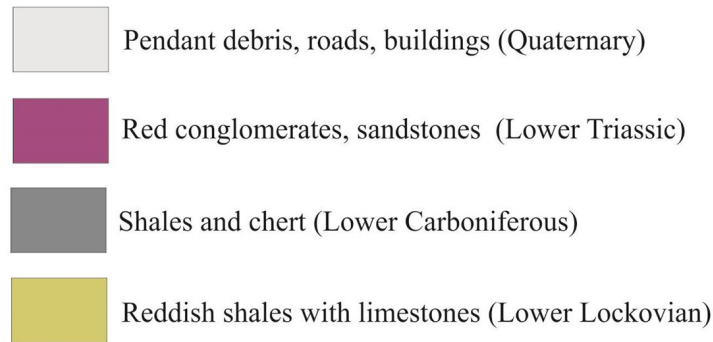

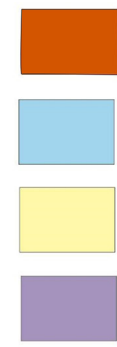

Black shales (Lockovian)

Nodular limestones (Pridolian)

Black shales (Wenlockian)

Black shales with chert (Llandoverian)

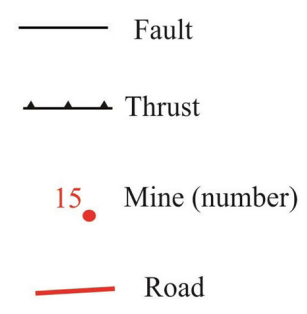

Figure 2

Geological map of the Gavà-Rocabruna area with indication of the iron mines and iron outcrops of this sector. shales (10-15 m thick, Pragian). The series at the top consists of green marls. The contact with the Carboniferous materials (Figure 2) has not been established in the area because all the contacts are tectonic. However, they are described at the southern part of the study area as black cherts ("lidites") of Tournaisian age and greenish graywackes of the Visean (Anadón et al., 1985b).

The Hercynian deformation largely affected the Paleozoic series of the area. It is described in the CGR domain by Julivert and Duran (1990b). A first stage of deformation produced NW-SE tight folds with the axial planes dipping to the NE. These folds have thrusts and retrothrusts on their flanks, and the black shales are the most common detachment level. A second phase of deformation produced folds with similar axial direction but opposite vergence. These folds can also contain detachments in the flanks. The deformation took place in the epizone, and axial-plane foliation is poorly developed. There is a very low-grade regional metamorphism. Contact metamorphism is absent in the study area, owing to the lack of Hercynian intrusives in this sector of the CGR. However, the Hercynian thrusts were associated with low-temperature hydrothermal circulation, which is more evident in Silurian and Devonian dolomitized-ankeritized limestones. The resulting rocks are yellowish to brownish and consist of ferrous saddle dolomite or ankerite, with crystals up to $2 \mathrm{~mm}$ in diameter. In addition, these rocks may contain disseminated pyrite with cubic crystals about $500 \mu \mathrm{m}$ in size, but in some cases they constitute nodules up to $3 \mathrm{~cm}$ in diameter. The sulfide content in these rocks rarely attains $\sim 1 \%$ modal. The Paleozoic rocks are unconformably overlain by Triassic sedimentary rocks that dip gently towards the SW (IGME, 1976a, 1976b). The Tri- 
assic series starts with a thick (more than $100 \mathrm{~m}$ ) Early Triassic detrital Buntsandstein facies that starts with conglomerates followed by sandstones and clays (Virgili, 1958). This is followed by about $50 \mathrm{~m}$ of limestones and dolomites of the Lower Muschelkalk facies (Calvet and Ramón, 1987), 50 $m$ of red clays and gypsum of the Middle Muschelkalk facies (Morad et al., 1995), and $50 \mathrm{~m}$ of limestones, dolostones, and marls of the Upper Muschelkalk facies (Calvet et al., 1987). Towards the SW the materials are covered by thick series of Jurassic and Cretaceous carbonates of the Garraf basin (Salas, 1987; Albrich et al., 2006). Large lull episodes in sedimentation favored the development of hard ground mineralizations along the stratigraphic profiles of the Mesozoic sediments. The Paleozoic rocks are unconformably overlain by the Paleogene series, which in the base start as continental rocks that can be related with the development of karstification and Fe-Mn mineralization in the underlying materials. These were followed by evaporitic and marine series that correspond to the transition with the marine series of the Ebro basin.

The Alpine deformation, as in other regions of the CCR, produced a dense network of Oligocene transpressive faults that strike mainly $\mathrm{NE}-\mathrm{SW}$ and NW-SE, thus resulting in complex block movements in the area (Guimerà, 1984). Several sets of subvertical joints, related with such faults, are widely distributed and affect all the materials in the area, in particular the dolostones. These joints represent good pathways for fluid circulation. Most transpressive faults were reactivated during the Neogene extension as normal faults, thus producing a compartmentalization of pre-existing blocks into horsts and grabens. The syntectonic sediments associated with this stage are mainly conglomerates due to graben infilling, along with sands and clays. Some Fe-Mn karstic mineralizations can also be associated with this episode.

During the early Pleistocene, weathering produced strong changes in the outcropping materials of the Paleozoic basement. Pyrite-bearing black shales were oxidized, and the resulting acidic and oxidizing fluids leached off the organic matter in the black shales. As a result, these rocks turned pale grayish near the surface, and typical sulfates and phosphates of the alunite supergroup were formed. These minerals were dated at 1.2 and 1.3 Ma (Calabrian/Villafranchian; Camprubí et al., 2003). Weathering also affected Paleozoic Fe-rich carbonates, thus producing karstic iron replacements (Costa et al., 1993) that were favored by jointing in the dolostones.

The Quaternary sediments are more common in the lowest part of the range, near the plain associated with the Llobregat River (Figure 1). Unconsolidated gravels are common in the flanks of the mountains, and sequences of calcretes, sedimentary clay deposits, and breccias can be found near the border between Paleozoic rocks and the graben (i.e., Solé-Benet et al., 1988; Casassas and Riba, 1992). The Llobregat delta plain consists of river terrace and flood plain deposits, and Pleistocene-Holocene paleochannels (Daura et al., 2013). The iron mines in the Gavà area strike NW--SE along a $2 \mathrm{~km}$ stretch section, between the Gavà town and the Bruguers chapel, $20 \mathrm{~km}$ west of Barcelona in Catalonia (Figure 2). Many of these mines were destroyed during the dense urbanistic operations of the 1960s- decade. However, in recent decades, the municipality of Gavà and the Catalan government enforced the study of all old mines in the area and, in many cases, the preservation of the Neolithic and Iberian mines. In this particular case, the Can Badosa area, which is an urbanistic polygon around an old farm in the Les Ferreres range, at the NW corner of the town of Gavà, comprises both Neolithic variscite mines and Iberian to modern iron mines. The archaeological excavations in recent years allowed the study of many of these mines, but many of the recently discovered Iberian mines are now covered by buildings and no further studies are possible anymore. 


\section{Methods}

Samples were studied using thin polished sections by transmitted and reflected light optical mineralogy, coupled with X-ray powder diffraction (XRD). The XRD measurements were performed using a Bragg-Brentano $\theta / 2$ Siemens D-500 diffractometer (radius $=200.5 \mathrm{~mm}$ ) with $\mathrm{Cu} \mathrm{Ka}$ radiation, selected by means of a secondary graphite monochromator, and a $\mathrm{NaI}(\mathrm{Tl})$ scintillation counter. The divergence slit was $1^{\circ}$ and the receiving slit $0.05^{\circ}$. The starting and the final $2 \theta$ angles were 4 and $70^{\circ}$, respectively. The step size was $0.05^{\circ} 2 \theta$ and the measuring time was 3 seconds per step. The analyses were performed at the Scientific and Techcnological Centres of the University of Barcelona (CGiTUB).

\section{Styles of iron deposits in the Gavà area}

Iron deposits in the study area were developed by replacement of three rock ensembles, which control the morphology and volume of the deposit as well as its resulting mineralogy: (a) deposits developed on weathered profiles in carbonates of the La Creu Formation (Pridolian), (b) deposits developed on weathered profiles in carbonates interbedded with shales of the Ludlow-Pridolian transition or within the Olorda Formation (Lockovian-Pragian), and (c) deposits in weathered profiles on carbonates overthrusted by Silurian shales.

\subsection{DEPOSITS IN WEATHERED PROFILES ON THE LA GREU FORMATION (PRIDOLIAN)}

The Pridolian carbonate rocks were strongly dolomitized or even ankeritized (Figure 3A), and easily affected by supergenic processes in their surface exposures. Also, some limestones were rich in pyrite nodules that underwent oxidation (Figure 3B) and produced supergenic acidic fluids. The replacement progresses along any discontinuities, either sedimentary (stratification surfaces, in par- ticular when the beds are subvertical), or structural (joints, thrusts, faults). In particular, joints were effective in favoring supergenic processes due to their penetrativity in dolomites. Further, dolomite rocks have additional porosity that was associated with the dolomitization processes, which increased the likeliness for these rocks to react with supergenic fluids. The supergenic mineralization is scarcely developed in depth and was confined to the first 3 to $5 \mathrm{~m}$ from the paleosurface, nonetheless. The morphology of the contacts between the mineralization and the host carbonates clearly corresponds to replacement processes and are irregularly shaped.

The iron oxide ore bodies occur as lenses, pipes, and pods. In most cases, lenses are developed along joints. The mineralized areas have a roughly lensoidal shape that are only a few centimeters wide on either side of the joints, but rarely up to 3 $\mathrm{m}$ wide. The length of these lenses is less than 15 $\mathrm{m}$, generally 2 to $3 \mathrm{~m}$ long. The pipes were usually formed along the intersection of two systems of joints or along the intersection of a joint and other types of discontinuity, such as faults or vertical stratification surfaces. Pipes are subvertical and their diameter varies between a few $\mathrm{cm}$ and $3 \mathrm{~m}$. Pods are very irregular and are generally located on the surface or in its vicinities. Their formation was probably favored by the intersection of three or more discontinuities in the rock. In fact, non-outcropping bodies appear to occur in the path of pipes or lenses from the surface. The size of pods is highly variable, but always less than $5 \mathrm{~m}$ in diameter.

The mineral filling started with a short period of calcite precipitation that could represent speleothems. The next stage may contain breccias, which are cemented by mixtures of cryptocrystalline goethite and hematite with minor amounts of wad. Therefore, the color of the ores may vary among different hues of yellow, brown, red, or black, hence their labeling as "ochres" following the definition of Elias et al. (2006). The breccias grade laterally and vertically to massive aggregates of these minerals. These minerals are usually ar- 

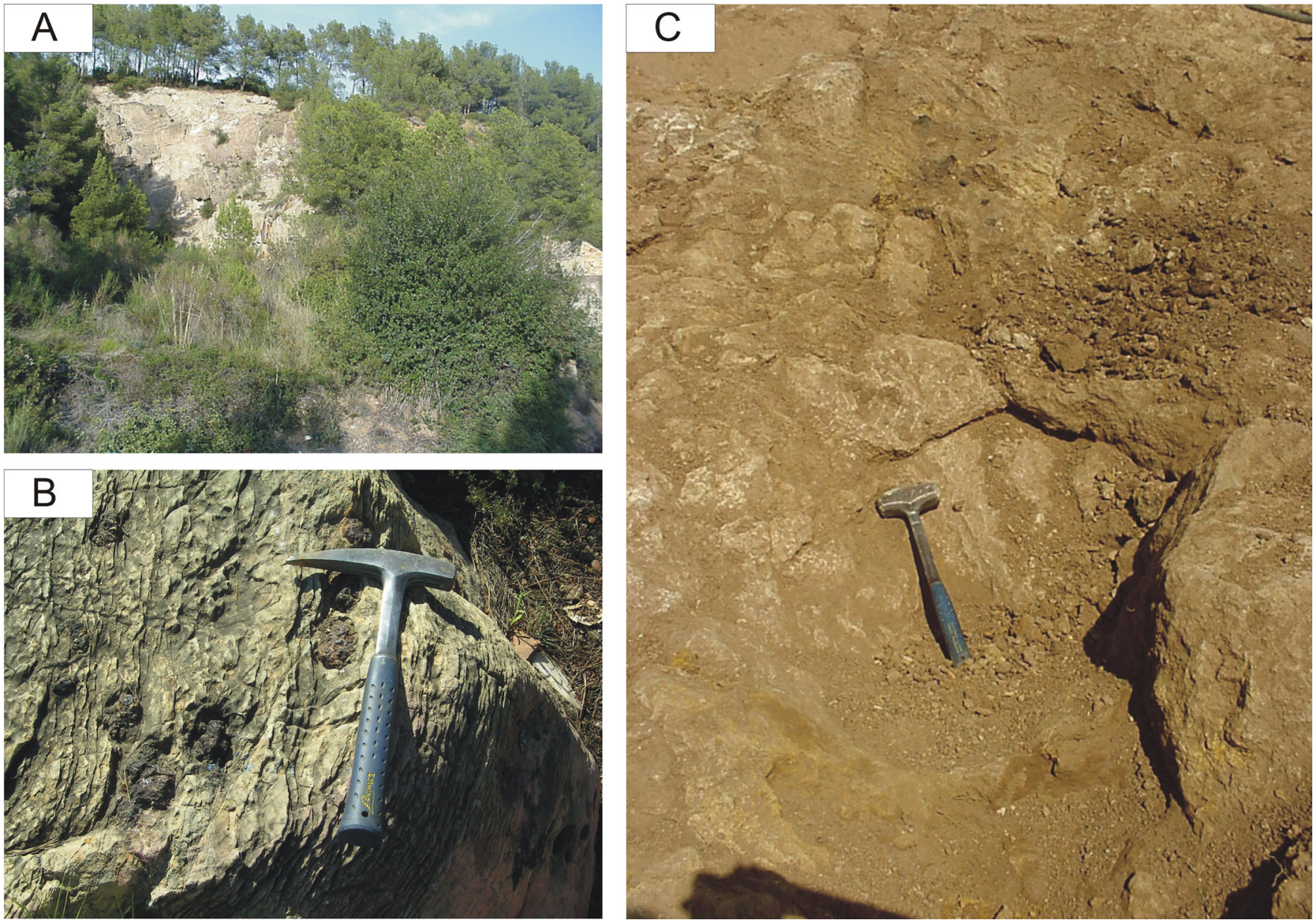

Figure 3 General aspects of the geological context of karst in Pridolian carbonates. (A) Dolostones (pale gray) replaced by ankerite (dark gray) in a quarry, 1 km NW of Gavà. (B) Dolomitized limestones (light gray) with pyrite nodules pseudomorphosed by goethite (dark brown). (C) Detail of the irregular replacement of the ankeritized limestones by iron oxides (black and yellow) near Can Badosa.

ranged in boxwork textures when replacing ironrich carbonates and the accompanying pyrite, and botryoidal textures are also common in these circumstances. However, in most cases, ore bodies are unconsolidated earthy masses of hydrated amorphous iron oxyhydroxides ("limonite"), mixed with cryptocrystalline goethite, hematite, and jarosite. Sedimentary textures and pisoliths are absent in these deposits. Late calcite veinlets and speleothems may occur in some deposits onto the remaining iron oxide ores left after their exploitation, thus pointing to a very recent formation.

Some representative ores of this type were found in the Can Badosa, area when excavating the foun- dations of a building in the immediate vicinity of the Neolithic mines. This type ofiron ores were locally mined (Figure 3C).

\subsection{DEPOSITS IN WEATHERED PROFILES ON GARBONATES INTERBEDDED WITH SHALES}

As in the previous case, some examples of weathered profiles on carbonates interbedded with shales deposits were found at the foundation of a building in the Can Badosa area (Figure 4). These deposits occur in the Lockovian series but have many similarities with others found in the transition unit between the Ludlovian shales and the 

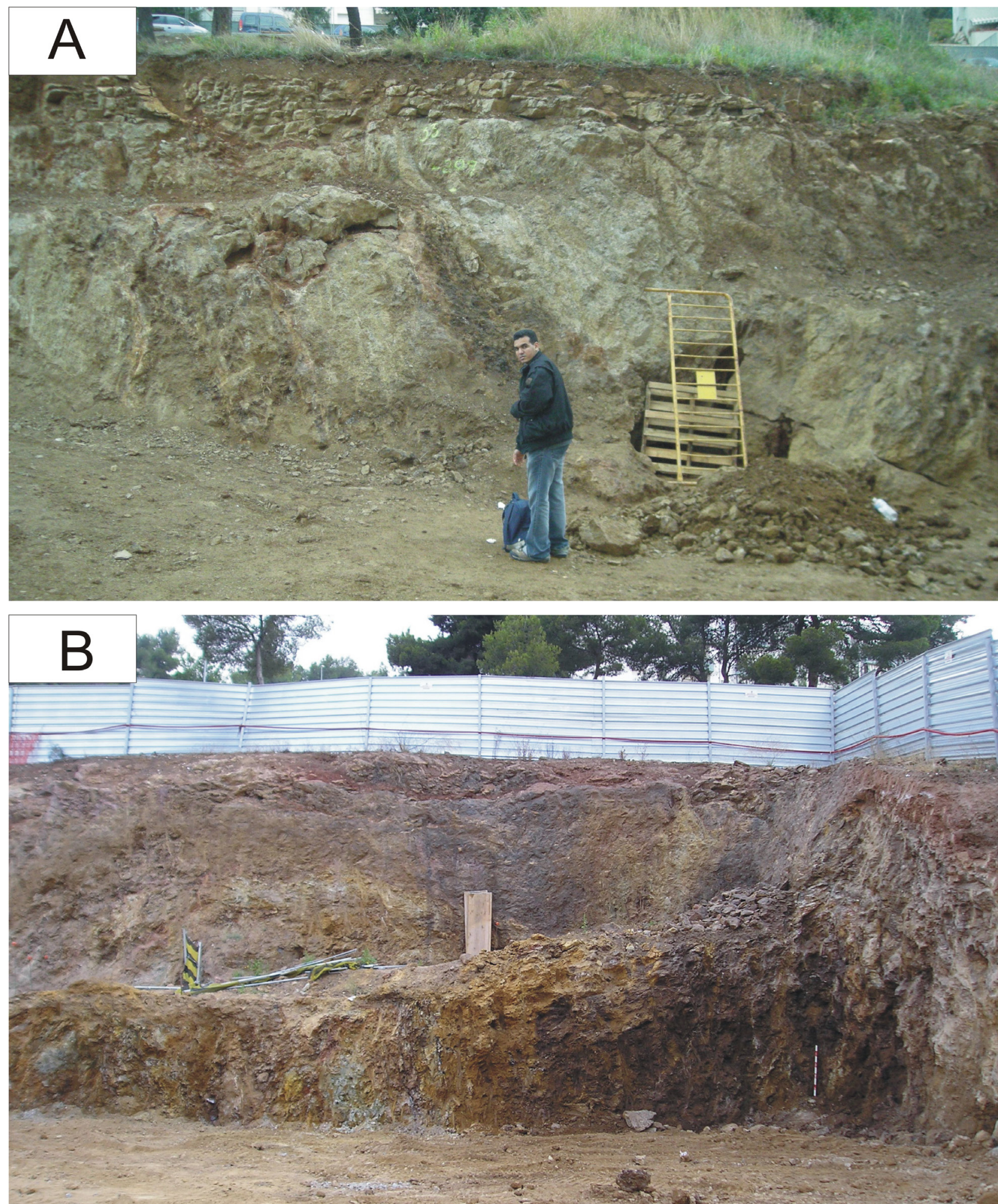

Figure 4 General aspects of the iron ores developed by alteration of carbonates interbedded with shales in the Can Badosa area. (A) Meter-thick altered dolostone beds (pale gray) interbedded with shales (dark). Note the mine at the right-hand side, partly shut. (B) Pervasive replacement of the shale and carbonate rock ensemble by iron oxides (yellowish and dark brown). Note some mine workings on the left-hand side. 
Pridolian carbonates. In all cases the host rocks are thin limestone lenses interbedded within pyrite-rich shales, that may be interbedded with phosphate beds as well, made up with cryptocrystalline fluorapatite. Therefore, the altered rock is geochemically more complex than in the previous style and the resulting ores after weathering contain abundant silicates and phosphates. The deposit is mainly controlled by bedding surfaces as the most suitable channels for water infilling but also by joints, thus resulting in pod-shaped ore bodies (Figure 4).

The Lockovian carbonate beds are also replaced by dolomite and ankerite, and weathering produces similar mixtures of oxyhydroxides and cryptocrystalline goethite, hematite, and jarosite as in the Pridolian limestones. However, the shales were enriched in pyrite and the resulting acidic fluids would have reacted with illite from the associated shales, which resulted in iron ores with relatively high silica contents in the form of opal. With higher degrees of replacement of the protoliths, the resulting ores may become massive, up to 10 $m$ in diameter pods with high iron oxides and opal contents. In other cases, the ore bodies are roughly tabular in shape and a few centimeters thick, as they mimic the shape of the replaced carbonates. In the cases where this process occurred in rocks with carbonate/shale ratios above 1 , the mineralization became almost massive and consists of a mixture of iron oxides, quartz, and illite or kaolinite. This style of mineralization occurs in the form of cryptocrystalline or even earthy aggregates, and consists mainly of goethite and "limonite"-type mineral mixtures.

\subsection{DEPOSITS IN WEATHERED PROFILES ON GARBONATES OVERTHRUST BY SILURIAN SHALES}

A significant example of this style is represented by the deposits in the Rocabruna area $(2 \mathrm{~km}$ NW of Gavà; Figure 1) in which large volumes of iron oxyhydroxides were formed. The Pridolian limestones were overthrusted by Silurian shales and supergenic alteration processes affected both lithologies (Figure 5A). This scenario resulted in a higher mineralogical and structural complexity than in the above mineralization styles. The main reason for this is that large volumes of carbonate rocks were fully replaced in the proximity of thrust surfaces. The resulting oxyhydroxide deposits are massive and irregularly shaped, and their size is on the order of hectometers in all directions. The distribution of massive ores is basically restricted to replaced carbonates, but minor enrichments are found in altered shales.

The oxyhydroxide ores in this style of deposits are rich in different types of phosphates (Costa et al., 1993), in particular Fe-Ca phosphates as white botryoidal hydroxylapatite $\left[\mathrm{Ca}_{5}\left(\mathrm{PO}_{4}\right)_{3}(\mathrm{OH})\right]$, greenish microcrystalline calcioferrite $\left[\mathrm{Ca}_{2} \mathrm{Fe}^{3+}{ }_{2}(-\right.$ $\left.\left.\mathrm{PO}_{4}\right)_{3}(\mathrm{OH}) \cdot 7 \mathrm{H}_{2} \mathrm{O}\right]$, yellowish cryptocrystalline tinticite $\left[\mathrm{Fe}^{3+}{ }_{5.34}\left(\mathrm{PO}_{4}\right)_{3.62}\left(\mathrm{VO}_{4}\right)_{0.38}(\mathrm{OH})_{4} \cdot 6.7 \mathrm{H}_{2} \mathrm{O}\right]$ (Bareche and Viñals, 1994; Camprubí et al., 1994; Melgarejo et al., 1988; Rius et al., 2000; Diez and Rosell, 2013), and reddish cryptocrystalline dufrénite $\mathrm{Ca}_{0.5} \mathrm{Fe}^{2+} \mathrm{Fe}^{3+}{ }_{5}\left(\mathrm{PO}_{4}\right)_{4}(\mathrm{OH})_{6} \cdot 2 \mathrm{H}_{2} \mathrm{O}$ (Tritlla, 1987). These phosphates formed in a late stage and occur either as nodules or veinlets filling small cracks across the goethite bodies, mainly along 2 $\mathrm{m}$ below the contact with the Silurian shales (Figure 5B). Moreover, jarosite is a common mineral in the contact between the thrust shales and the ore bodies, and is found forming yellowish or greenish cryptocrystalline massive aggregates (Figure $5 \mathrm{C}$ ) that can be associated with calcioferrite, tinticite and dufrénite. Alunite is also found as white, earthy cryptocrystalline masses along the thrust contact (Figure 5D; Camprubí et al., 2003). The oxide ores are the same as those described in the Can Badosa mines and show the same textures. The occurrence of carbonate minerals is less common in this style of mineralization than in the previous two.

\subsection{DISTRIBUTION OF IRON MINING OPERATIONS IN THE GAVÀ AREA}

The geological mapping of the area combined with bibliographic research and archeological studies performed during the urban developments in the last 30 years allow the identification of more 

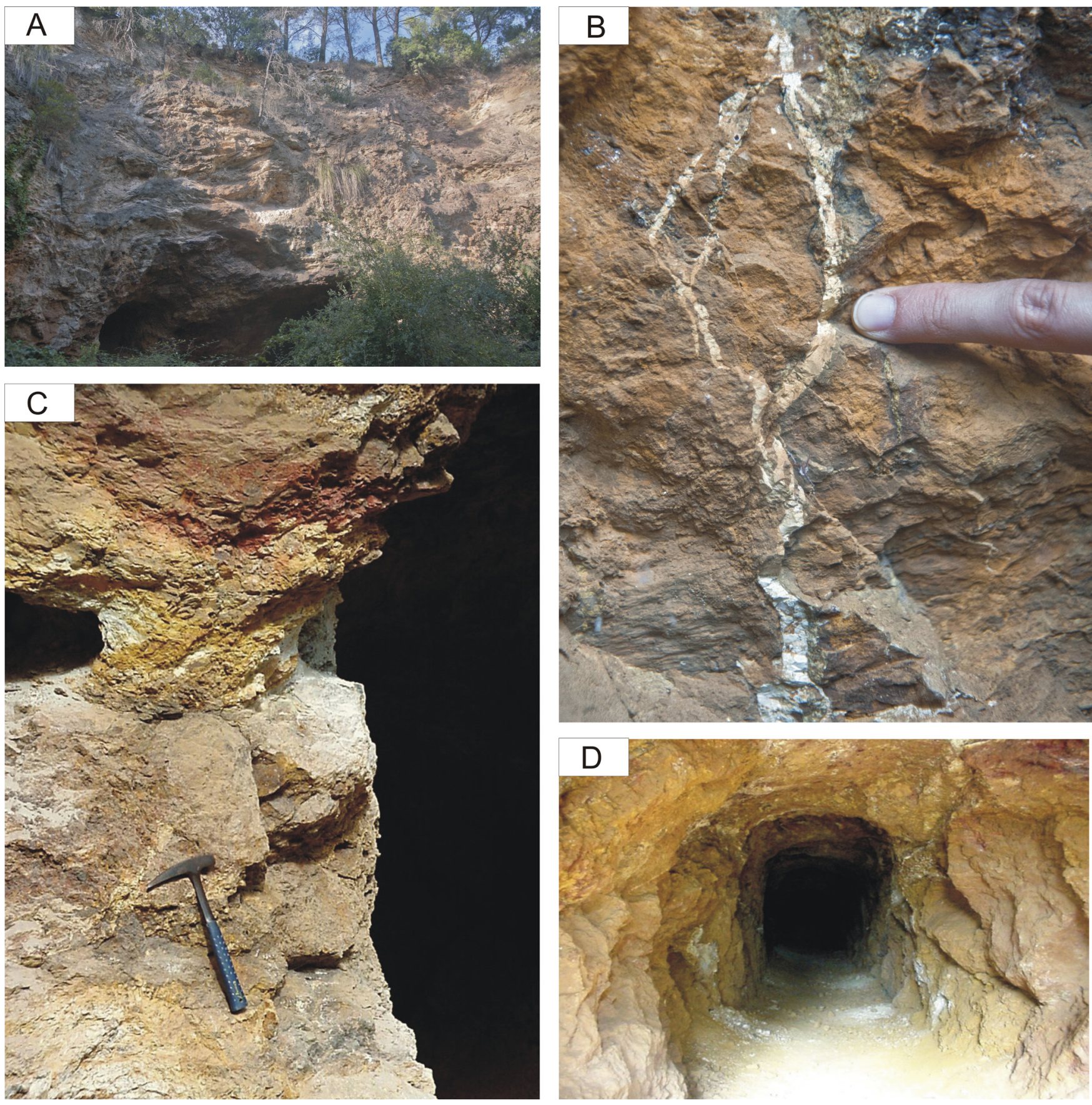

Figure 5 Field aspect of the massive iron ores developed on Pridolian carbonates overthrusted by pyrite-rich Silurian black shales at the Rocabruna mines, Gavà. (A) Top of the Rocabruna quarry, with the overthrust altered shales, enriched in iron ores. (B) Tinticite veins (yellow) cutting massive goethite bodies produced by replacement of ankeritized Pridolian limestones. (C) Subhorizontal contact between the overthrust shales (strongly replaced by goethite, upper half of the image) and the Pridolian carbonates replaced by goethite (dark brown, lower half of the image). (D) Alunite intergrowths (white coloured) crystallized over the thrust surface that roughly follows the top of the mining gallery. The lower part of the image shows entirely massive iron oxides. 
than 50 old iron mines in the Gavà municipality. The mines occur within a $2 \mathrm{~km}$ long and 0.5 km wide belt between Gavà and Bruguers, NW of Gavà (Figure 2). There are two main mining areas concentrated at the Les Ferreres range (the "Ironworks" range) and the Rocabruna area (the "Brownish Rock" area). This toponym is related to the brownish color of iron-rich rocks and is typically used for areas with iron mines in Catalonia since the Middle Ages.

The geological study of most of the iron mines was performed as the archeological excavations progressed. This aspect was important in order to discriminate between the Neolithic variscite mines

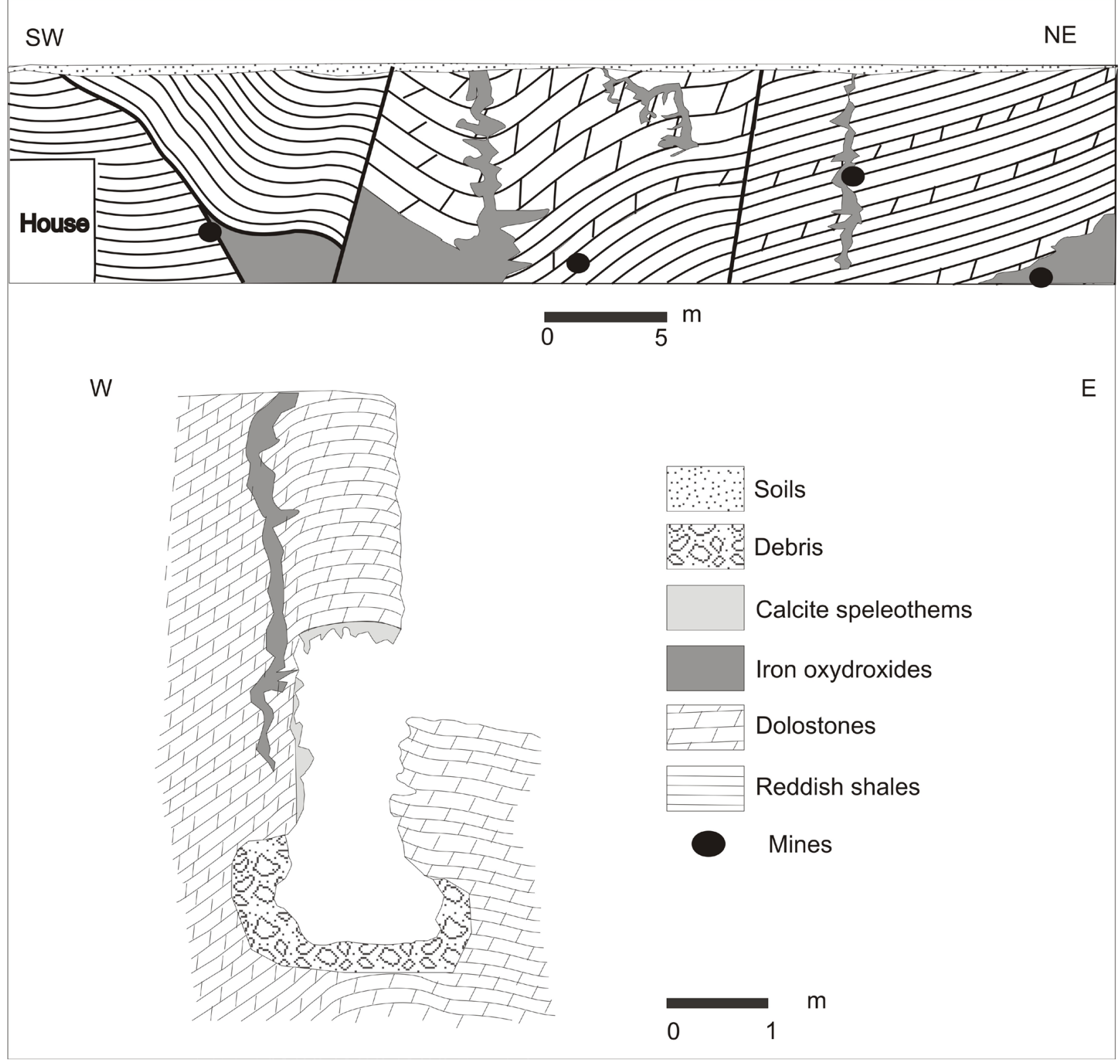

Figure 6 Top: Geological section along the foundation of a building on Pompeu Fabra Avenue in Gavà showing the location of the iron mines. Bottom: Geological section of an iron mine in the same area. 
(see Díaz-Acha et al., 2019) and more recent iron mines, especially where both types of mines occur nearby each other. Both artisanal and industrial mineral operations can be recognized in Gavà. It is not clear, however, whether industrial mines were developed in areas that were previously mined in an artisanal manner. All the exploitations were developed on altered carbonate-bearing rocks (Figures 4 to 6 ).

\section{Description of the mining operations}

\subsection{ARTISANAL MINING IN THE GAN BADOSA AREA}

One of the first Iberian mining operations, discovered in Gavà, was mine 65 (Figure 2 and 7), which was minted during the rule of the Roman emperor Trajan. This mine has been dated between the
I and II centuries AD based on a coin found inside the mine. (Arenas et al., 1989; Álvarez et al., 1991). This mine consists of a large trench $(16.5 \mathrm{~m}$ long and $5.3 \mathrm{~m}$ wide). A small prospecting pit (mine 63, interpreted as older than mine 65) was found in its proximity. Similar open pits were found thereafter during archeological excavations (i.e., mine 82; Estrada and Bosch, 1997), and some of the outcrops of the southern part of Can Badosa represent this style of mine operations (Figure 3C).

A large number of small artisanal operations (mines 97-101, 103-105) were found when constructing the foundations of a building near Pompeu Fabra Avenue on the outskirts of Gavà. Many small karstic cavities were found in the study area, but they do not show credible evidence for historical mining operations. Most of the artisanal mines were developed as vertical pits and, therefore, are filled with natural debris. Although many of the

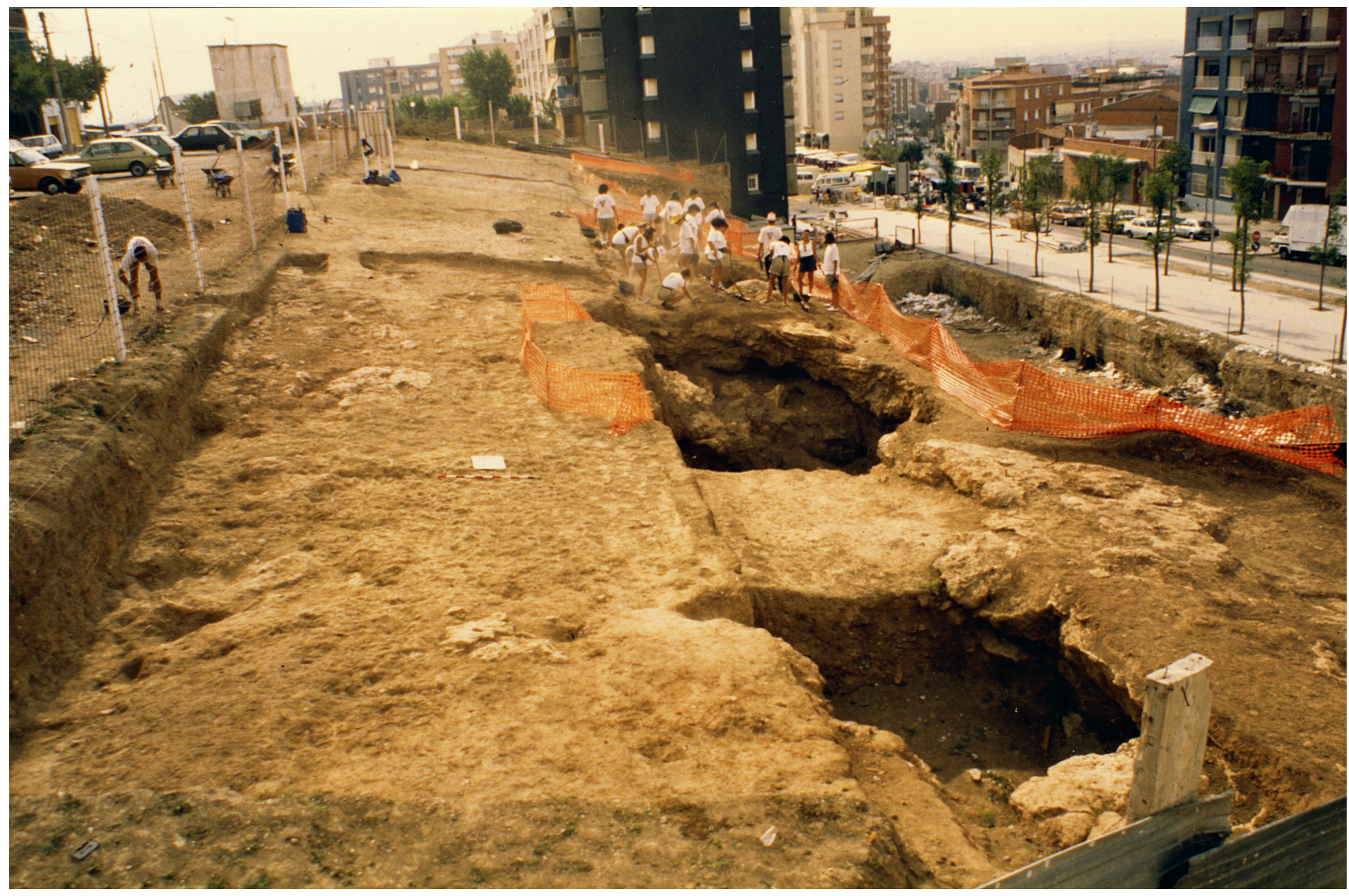


mines have not been completely excavated, they have been sealed and protected in order to facilitate future archeological research. These mines consist of small pits (1 to $3 \mathrm{~m}$ deep) that were dug directly on outcropping ore bodies (i.e., mine 105 in Figure 6). These pits can give access to short galleries, less than $3 \mathrm{~m}$ long. The galleries and pits section tends to be rounded and it is less than 1.5 $\mathrm{m}$ in diameter, However it galleries are generally irregular because the miners carefully extracted as much as possible the iron ores. Therefore, the extraction of ores and the general work inside these mines was complicated, and the geometric characteristics of some of the mines suggest that they were probably exploited by children. After the extraction of iron ore, some mines experienced water infiltration that produced the development of calcite speleothems (Figure 6).

\subsection{ARTISANAL TO INDUSTRIAL MINING IN THE ROGABRUNA MINES}

Campmany et al. (2004) describe historical documents about the mining activity and the ore processing by the Catalan forge system in the area during the Middle Ages. The forges were located both in Gavà and Bruguers; hence, the forges were most likely fed by material extracted from the Rocabruna mines. The oldest activity registered in the area corresponds to the year 1068. At that time the area was near the frontier between the county of Barcelona and $\mathrm{Al}-$ Andalus, and was considered a territory in conflict. Therefore, the products of the iron mines and the associated forges could have had a strategic importance in war. The mining and forge activities continued at least during the twelfth and thirteenth centuries, and ceased at the

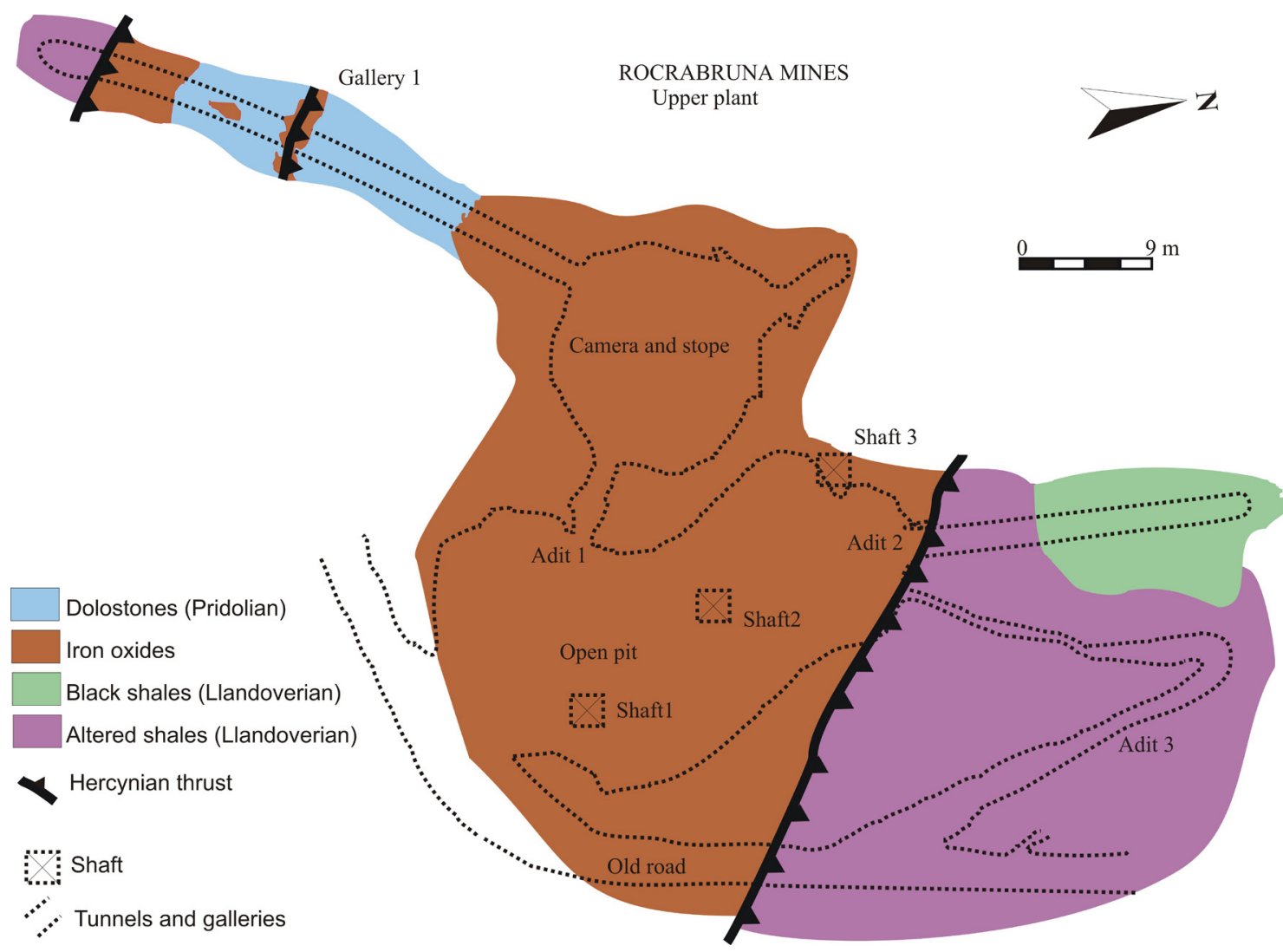

Figure 8 Open pit of the nineteenth century, and upper levels of the 1940s mining works, at the Rocabruna mines. Notice the control on the location of ores exerted by Hercynian thrusts. 
end of the Middle Ages (Campmany et al., 2004). The Rocabruna mines were reopened in 1770 and ceased again shortly thereafter (Campmany et al., 2004). There is no data about the exploitation system during this period, but the ore bodies were probably exploited by means of trenches.

During the period 1860-1861 the mines were reopened to furnish iron mineral to a forge at Sants (Bauzá, 1861), today a district of Barcelona. During this period the mines were exploited by open pits of reduced dimensions (less than $50 \mathrm{~m}$ in diameter, Figure 5A), but the mining company went bankrupt and mining ceased (Bauzá, 1861). New operations using small open pits were per- formed in other iron outcrops of the area during the period 1876-1878. The mines were exploited once more following the same system during the period 1888-1908 and at that time the mineral was exported to be processed in France (Maureta and Thos, 1881). However, the dimensions of the mines exploited between the nineteenth century and the beginning of the twentieth century allows estimating a production of less than 50000 tons in total.

The last and more important period of activity of these mines was during the autarchy period of the Francoist dictatorship, during the 1940s and $1950 \mathrm{~s}$, at the end of this period mining ceased

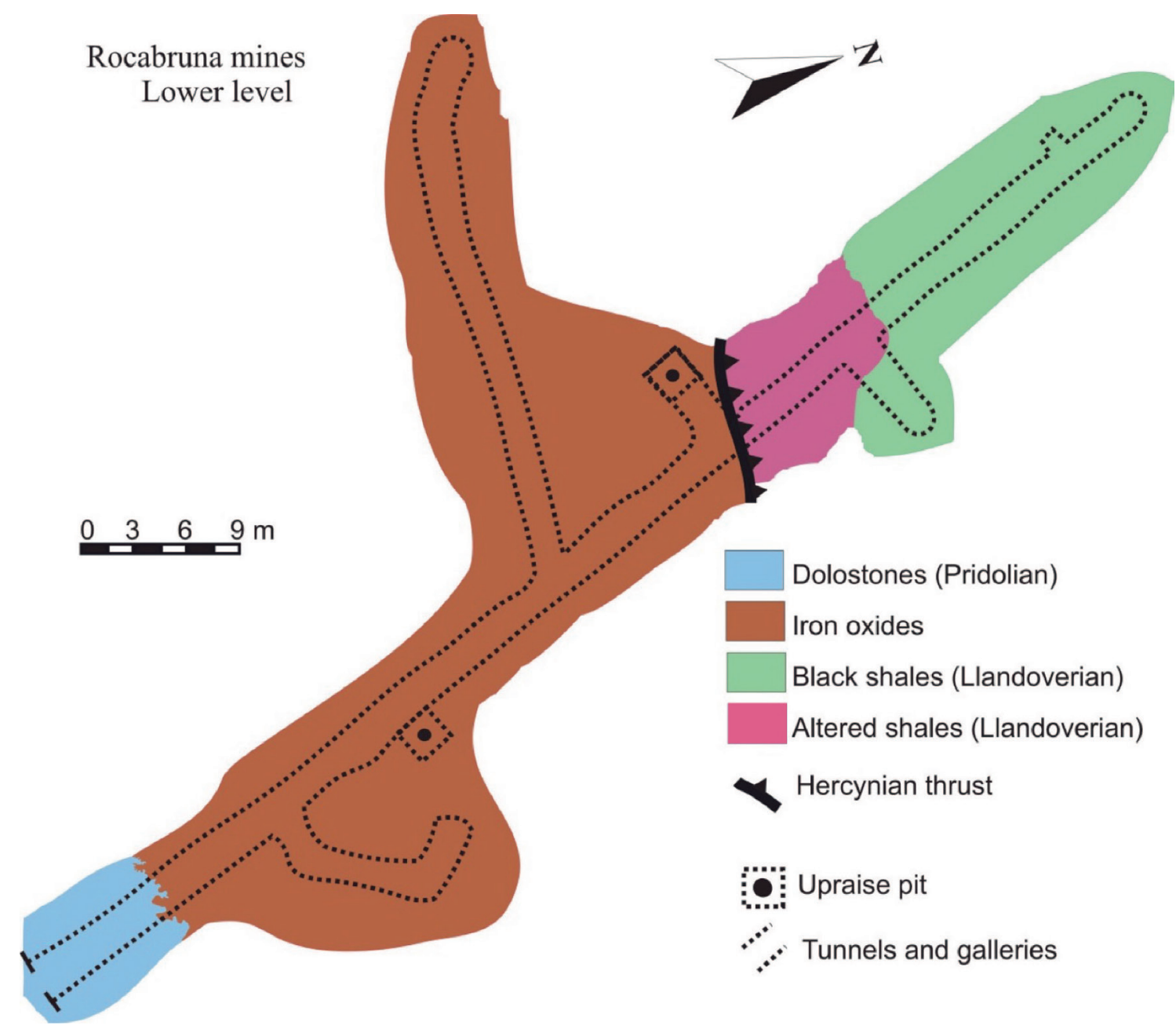

Figure 9 Open pit of the nineteenth century, and upper levels of the 1940s mining works, at the Rocabruna mines. Notice the control on the location of ores exerted by Hercynian thrusts. 
definitively in the area (Campmany et al., 2004). During this period some horizontal tunnels were built starting from the bottom of the open pit (Figure 8). One of the tunnels gave service to a large stope to exploit the iron ores. A gallery of reconnaissance started from the stope (gallery 1 in Figure 8) and found small irregular pods of ore replacing dolostones at the contact with Hercynian thrusts, but the replacement of carbonate rocks was only partial and therefore the distribution of the ore was very irregular, and the gallery was subsequently closed. Other exploratory galleries were planned without geological criteria. For instance, the gallery starting at the adit 2 (Figure 8) also found ore, but the exploitation did not continue entered the black shales.

The mineral obtained from these galleries was sent through shafts to a lower plant mainly used for mineral evacuation. This lower plant consisted of an access tunnel with some lateral galleries for ore reconnaissance (Figure 9). The continuity at depth of the ore bodies was demonstrated in these galleries but they never were exploited at this level. The mineral was extracted through the adit of this mine and sent to the processing plant.

\section{Discussion}

\subsection{FORMATION OF IRON ORES IN THE GAVÀ AREA}

The iron ores in the Can Badosa-Les Ferreres range area are essentially hosted by Pridolian massive limestones, which are the main guides for finding old iron mines in the Gavà region (Costa et al., 1993). Also, some artisanal works were established on minor deposits that are hosted by dolostones interbedded with shales of the Silurian-Devonian transition. The outcrops of the carbonate rocks are not continuous and the Paleozoic tectonic structure in the area is complex. The limestones are segmented because of thrusting and Alpine faults, factors that limit the development of large deposits.
The morphology of the iron ores at Can Badosa corresponds to vertical karstic shafts and small chamber rooms, following the terminology of Loucks (1999). These deposits were formed by replacement of the carbonate rocks within the vadose zone near the Quaternary paleosurface. This domain is not able to produce large cavities in the karstic realms (Loucks, 1999). The volume of individual iron ore bodies in the study area is limited in most cases due to the small thickness of carbonate beds or by the low amount of available iron in these rocks. Therefore, these deposits do not meet the current economic criteria for industrial mining operations, but their mining would have been feasible by artisanal exploitations, as shown by those mines active during the Iberian and Roman times, and during the Middle Ages.

All the iron oxyhydroxide deposits in the study area are karstic in origin (common around Barcelona), similar to those described in many locations along the CGR (Mata-Perelló and Montoriol-Pous, 1975; Mata-Perelló, 1990). These type of iron mines were exploited in industrial times without significant profit. Other iron deposits, also developed on weathered limestones, are found in the vicinity of El Vendrell (60 km SW of Gavà). These deposits also have reduced dimensions and were also exploited during the pre-Roman Iberian epoch (Morer and Rigo, 1999).

The formation model for iron deposits along the CGR is variable. A sedex-type origin was proposed for the Malgrat iron mines near the Catalan coast (Carmona and Viladevall, 1983, 1985) and an epithermal origin was suggested for the Celrà iron mines in NE Catalonia (Ferrer-Modolell, 1991). However, the irregular morphology produced by replacement, the botryoidal and earthy textures, and the poorly crystalline character of most iron ores of the CGR suggest that these deposits were produced by edaphic processes, in part coupled with karstic development. The controls of the ores are lithologic (availability of iron-rich carbonates), paleogeographic (proximity of the Quaternary paleosurface, less than $5 \mathrm{~m}$ deep), and structural 
(presence of discontinuities as joints and faults). The Can Badosa karstic deposits could be classified as immature, as the karst was developed by fluids, circulating vertically by gravity, within the vadose zone (as described by Loucks, 1999). The Can Badosa and Rocabruna deposits exhibit significant mineralogical differences between them, such as the occurrence of minerals of the alunite supergroup and iron phosphates in Rocabruna, which are absent in Can Badosa. Also, the deposits are much larger in the Rocabruna than in the Can Badosa group of deposits.

The occurrence of large amounts of alunite and jarosite in the Rocabruna deposits is a key factor to recognize the effects of acidic fluids involved in the genesis of the deposit and to explain its size and grade. A hydrothermal origin is not an exclusive source for acidic and oxidizing fluids, and such solutions can be produced by weathering below paleosurfaces of sulfide-rich rocks (Melgarejo et al., 1997; Borruel-Abadía et al., 2016), a role that is played effectively by the overthrusting Silurian shales in the study area. Weathering processes may develop economic deposits of alunite-group minerals, such as those developed on similar Silurian black shales in central Spain (Caballero et al., 1974; Cañada, 1974). Such processes may also produce economic iron oxyhydroxide deposits on the surface, as is the case of the Riaza deposits in central Spain (Leal-Meca and Lillo-Ramos, 2009). Therefore, the acidic oxidizing fluids that result from the oxidation of pyrite are able to transport leached iron towards deeper parts of the weathering profile where, in the case of the studied deposits, Pridolian carbonates were found. The neutralization of the acidic fluids when reacting with the carbonates would have produced (1) the precipitation of sulfates of the alunite group at the contact between the shales and the carbonate rocks, and (2) the replacement of iron-rich carbonates and precipitation of iron oxyhydroxides at higher $\mathrm{pH}$ and below the contact. Therefore, the sources of iron at the Rocabruna deposit could be both the iron coming from the dissolution of Fe-rich dolostones and the iron transported by the descending super- genic acidic fluids, whereas the likeliest source of iron in the Can Badosa deposits would be the dissolution of Fe-rich dolostones alone. Consequently, the downward incorporation of acidic fluids helped to produce larger deposits at Rocabruna than in Can Badosa by increasing the replaced volume and supplying additional Fe. Moreover, the dissolution of apatite in the overthrusting $\mathrm{Si}$ lurian shales by acidic fluids is responsible for the formation of descending $\mathrm{H}_{3} \mathrm{PO}_{4}$-enriched fluids, which would have reacted with $\mathrm{Ca}-\mathrm{Fe}$ carbonates and oxyhydroxides to form iron-rich phosphates. The existence of deep weathering profiles suggests that these deposits were formed under a humid climate. Dating of the alunite associated with supergenic ores in the Gavà area yielded Calabrian-Villafranchian ages (late Pliocene; Camprubí et al., 2003). These ages are in accordance with palynological studies in sediments from other areas of Catalonia, which suggest that the climate during the early to middle Pleistocene was warm and humid (Postigo Mijarra et al., 2007).

Iron ore deposits in paleokarsts have been intensively mined worldwide between prehistoric times and the nineteenth century because they were highly suitable for metallurgical extraction of iron (Bárdossy et al., 2015). In some cases, as in Belgium, the richest deposits occur in deposits similar to Rocabruna; that is, limestones overthrust by shales (Denayer, 2016). In fact, pre-existing concentrations of iron ores are considered necessary to produce large iron deposits by supergenic processes, as proposed to explain the iron enrichments in the large mines of Marquesado, Alquifes and Las Piletas near Granada, southern Spain (Torres-Ruiz, 1983).

\subsection{GONDITIONS FOR EARLY IRON MINING IN THE GAVÀ AREA}

The morphology and mineralogy of the deposits are crucial factors that control the feasibility of exploitations through history. The existence of relatively soft oxyhydroxide ores, similar in texture and mineralogy to those classically known as "bog 
ore", could have favored artisanal mining between the Iberian and Roman historical periods. Such is the case of many other locations in Europe during pre-Roman times (i.e., Thelemann et al., 2017). The porous nature of the ores could have favored reducing reactions (Tylecote, 1992) as such as ores were suitable for iron reduction in bloomery (i.e., Sauder and Williams, 2002).

The studied iron mines were near populated centers since the Iberian period. Despite the reduced dimensions of the mined ore deposits, these could have been large enough to feed the local demand within a subsistence economic scheme. Therefore, such ores would have supported the sort of mining operations that could be developed during the Iberian or Iberian-Roman periods, and such a possible age for the earliest iron mining in the region is also supported by archeological evidence (Arenas et al., 1989; Álvarez et al., 1991). Also, the forges that would have been fed by mining activities in these ores were active during the Middle Ages, as documented by Campmany et al. (2004).

Some of the oldest mines in Europe were opened to exploit iron ochres for pigments, such as a mine in Greece that was dated at 2,000 BP (Levato, 2016). The studied iron mines share the same geological context and mineralized areas with the Neolithic variscite mines of Gavà, which makes a strong case for both types of mines to be exploited simultaneously, although there is no convincing evidence for mining of iron ores in the Gavà area earlier than the Iberian period.

The Can Badosa iron ores are silica-poor in the Pridolian carbonates, but silica-rich in the Lockovian carbonates. The silica-rich ores would have hindered the Iberian period metallurgy by generating large volumes of slag. The Rocabruna ores, with high contents in phosphates, could have produced lower quality metal objects that would have been harder than P-poor objects but slightly more brittle (Sarabia, 1994).

\section{Conclusions}

The iron ores of the Gavà domain were formed by karstic processes developed during the late Pliocene and the Quaternary on Fe-rich dolostone units of Silurian-Devonian age. The dimensions of these deposits are quite reduced owing to the scarce thickness of the Paleozoic carbonates and the compartmentalization of the outcrops by their structural arrangement.

The ore grade decreases with increasing silicate content in the protolith (Lockovian or Ludlovian) due to interbedding between carbonate rocks and shales. Also, the ore size and grade ores increase, and the mineralization become massive, when carbonates were replaced by acidic fluids due to the oxidation of pyrite in overthrusting pyrite-rich shales.

Karstic ores consist mainly of cryptocrystalline goethite and hematite, often as unconsolidated aggregates. Such textures and mineralogy favored artisanal mining of these ores during antiquity.

Archeological evidence indicates that all the styles of iron ores in the Gavà area have been exploited at least since the Iberian historical period. Iron mining has been intermittently active in this area through history, essentially during the Roman epoch, the Middle Ages, and the industrial period. For the latter two cases, historical documental records are available. The earliest artisanal iron ore exploitations were designed using trenches, pits, or shafts along all the available outcrops and all the styles of mineralization. Iron mining during the Neolithic cannot be ruled out.

Between the nineteenth and twentieth centuries the development of industrial mining was restricted to the largest deposits by means of open pits. In these cases, it is likely that any evidence for earlier mining activities has been destroyed. 


\section{Acknowledgements}

This paper is a contribution to the projects 2014 SGR 1661 and 2014/100820 of the Government of Catalonia (Generalitat de Catalunya), which provided the necessary funds. The Municipality of Gavà and the Gavà Museum helped in the study of the archeological sites and Elisenda Miquel of the Gavà Environmental Department helped to allow access to many areas of the municipality for geological mapping. Some of the samples used in this study were provided by the Mineralogy Collection of the University of Barcelona and by the Natural Sciences Museum of Barcelona. The authors acknowledge the revisions by the referees Dr. María del Sol Hernández Bernal and Dr. Giovanni Sosa Cevallos.

\section{References}

Albrich, S., Bernaus, J.M., Boix, C., Caus, E., Martín-Closas, C., Salas, R, Vicedo, V., Villalonga, R., 2006, Caracterización bioestratigráfica y paleoambiental del Cretácico inferior (BerriasienseBarremiense) del Macizo de Garraf (Cadena Costera Catalana): Revista Española de Micropaleontología, 38, 429-452.

Alonso, M., Edo, M., Gordo, L., Millán, M., Villalba, M.J., 1978, Explotación minera neolítica en Can Tintoré (Gavà, Barcelona): Pyrenae, 13-14, 7-14.

Álvarez, R., Estrada, A., 2009, L'explotació de ferro en el complex miner de Gavà. La mina n. ${ }^{\circ}$ 65: La nostra gent, 5, 141-160.

Álvarez, R., Blasco, M., Burjachs, F., Estrada, A.I., Sintas, E., 1991, Memòria de l'excavació al solar situat al carrer de Roger de Flor de Gavà (Baix Llobregat): Gavà, Catalonia, Museu de Gavà, Unpublished Report. Anadón, P., Colombo, F., Esteban, M., Marzo, M., Robles, S., Santanach, P., Solé Sugrañés, L.,
1979, Evolución tectonoestratigráfica de los Catalánides: Acta Geologica Hispanica, 14, 242-270.

Anadón, P., Cabrera, L., Guimerà, J., Santanach, P., 1985a, Paleogene strike-slip deformation and sedimentation along the Southeastern margin of the Ebro basin, in Biddle, K.T., Christie-Blick, N., (eds.), Strikeslip deformation, basin formation and sedimentation: Oklahoma, USA, Society of Economic Paleontologists and Mineralogists Special Publication, 37, 303-318.

Anadón, P., Julivert, M., Sáez, A., 1985b, Aportación al conocimiento del Carbonífero de las Cadenas Costeras Catalanas (abstract), in Compte rendu X Congrès International de Stratigraphie et de Géologie du Carbonifère, 1983: Madrid, Spain, Instituto Geológico y Minero de España, 1, 99-106.

Arenas, J., Cebrià, A., Estany, I., 1989, Memòria de la prospecció i excavació d'urgència a la U.A.1 de Can Tintorer, Gavà (Baix Llobregat); mines 62 i 65 i punts 63 i 64: Barcelona, Spain, Servei d'Arqueologia, Generalitat de Catalunya, Unpublished Memory.

Asensio, D., Ferrer, C., Morer, J., Pou, J., Sabaté, G., 1996, El poblament ibèric al Vendrell. Estat de la qüestió: Miscel lània Penedesenca, 24, 57-69.

Bárdossy, G., Fuchs, Y., Glazek, J., 2015, Iron ore deposits in paleokarst, in Bosák, P., Ford, D., Glazek, J., Horácek, I. (eds.), Paleokarst. A systematic and regional view: Amsterdam, the Netherlands, Elsevier, 419-430.

Bareche, E., Viñals, J., 1994, Els fosfats a Bruguers (Baix Llobregat, Catalunya) : Mineralogistes de Catalunya, 6, 3-5.

Bauzá, F., 1861, Informe de la visita verificada al distrito minero de Barcelona: Revista Minera, Periódico científico e industrial, 12, 401-485.

Belarte, M.C., Pou, J., Sanmartí, J., Santacana, J., 2001, Tècniques constructives d'època ibèrica i experimentació arquitectònica a la 
Mediterrània (abstract): Barcelona, Spain, Universitat de Barcelona, Departament de Prehistòria, Història Antiga i Arqueologia, Actes de la I Reunió Internacional d'Arqueologia de Calafell, 27-41.

Blasco, A., Edo, M., Villalba, M.J., 1991, Les perles en Callaïs du Sud de la France proviennentelles des Mines de Can Tintorer?: Montpellier, France, Conseil Général de l'Hérault, Le Chalcolithique en Languedoc, ses relations extra-regionales (Saint Mathieu de Tréviers, 1990), Archéologie en Languedoc, Colloque International Hommage au Dr. Jean Arnal, 279-289.

Bordas, A., Molinas, R., Saa, M., 2009, La mineria del ferro a Gavà. Darreres intervencions arqueològiques a la serra de les Ferreres: La nostra gent, 5, 161-176.

Bordas, A., Molinas, R., Saa, M., Melgarejo, J.C., Lehbib, S., 2010, Les mines històriques al sector de la serra de Les Ferreres: darreres aportacions a l'estudi de la mineria del ferro a Gavà: Rubricatum, 4, 247-262.

Borrell, F., Estrada, A., 2009, Elements ornamentals neolítics de variscita trobats a les mines 83 i 85 de Gavà, in Bosch, J., Borrell, F. (eds.): Intervencions arqueològiques a les Mines de Gavà (sector serra de les Ferreres), Anys 1998-2009, De la variscita al ferro: neolític i antiguitat: Rubricatum, 4, 171-181.

Borruel-Abadía, V., Barrenechea, J.F., GalánAbellán, A.B., Alonso-Azcárate, J., De la Horra, R., Luque, F.J., López-Gómez, J., 2016, Quantifying aluminium phosphatesulphate minerals as markers of acidic conditions during the Permian-Triassic transition in the Iberian Ranges, E Spain: Chemical Geology, 429, 10-20.

Bosch, J., Estrada, A., 1994, La Venus de Gavà (Barcelona). Una aportación fundamental para el estudio de la religión neolítica del suroeste europeo: Trabajos de Prehistoria, 51, 149-58.
Bosch, J., Estrada, A., Noain, M.J., 1996, Minería neolítica en Gavá (Baix Llobregat, Barcelona): Trabajos de Prehistoria 53, 59-71.

Burjachs, F., Álvarez, R., Blasco, M., Estrada, A., Sintas, E., 1991, Las minas de hierro en época ibérica tardía de Gavà (Barcelona), in Actas XXI Congreso Nacional de Arqueología: Zaragoza, Spain, Diputación General de Aragón, Departamento de Educación y Cultura, 825-836.

Caballero, A., Meléndez del Valle, E., MartínVivaldi, J.L., 1974, Yacimientos españoles de bauxitas y alunitas: Boletín Geológico y Minero, 85, 32-42.

Calvet, F., Ramón, X., 1987, Estratigrafía, sedimentología y diagénesis del Muschelkalk inferior de los Catalánides: Cuadernos de Geología Ibérica, 1 1, 141-169.

Calvet, F., March, M., Pedrosa, A., 1987, Estratigrafía, sedimentología y diagénesis del Muschelkalk superior de los Catalánides: Cuadernos de Geología Ibérica, 11, 171-197.

Campmany, J., Albaigés, M., Cano, R., Cociña, P., Santmartín, A., 2004, Les Mines de Ferro de Rocabruna (Gavà): Materials del Baix Llobregat, 10, 71-77.

Camprubí, A., Costa, F., Melgarejo, J.C., 1994, Mineralizaciones de fosfatos férricoalumínicos de Gavà (Catalunya): tipología: Boletín Geológico y Minero, 105, 444-453.

Camprubí, A., Melgarejo, J.C., Proenza, J.A., Costa, F., Bosch, J., Estrada, A., Borrell, F., Yushkin, N.P., Andreichev, V.L., 2003, Mining and geological knowledge during the Neolithic: a geological study on the variscite mines at Gavà, Catalonia: Episodes, 268, 295-301.

Cañada, F., 1974, El yacimiento de alunita de Negredo (Segovia). Consideraciones sobre su génesis: Boletín Geológico y Minero, 85, 430-435. 
Carmona, J.M., Viladevall, M., 1983, Estudio geológico del sector oriental del macizo paleozoico del Montnegre (provincia de Barcelona): Revista de Investigaciones Geológicas, 36, 83-96.

Carmona, J.M., Viladevall, M., 1985, Morfología y mineralogénesis de las concentraciones de hierro del macizo paleozoico del Montnegre, Malgrat-Calella (provincia de Barcelona): Revista de Investigaciones Geológicas, 40, 65-86.

Casassas, L., Riba, O., 1992, Morfologia de la Rambla barcelonina: Treballs de la Societat Catalana de Geografia, 7, 9-27.

Coll, J.M., Molina, J.A., Roig, J., 1993, El poblament protohistòric de la conca alta del riu Ripoll: de l'Edat del Ferro a la fi del món ibèric: Limes, 3, 41-52.

Costa, F., Camprubí, A., Salvany, M.C., Sáez, G., Arcas, A., Melgarejo, J.C., 1993, The phosphate mineralizations from Gavà, Catalonia, Spain, in Fenoll Hach-Ali, P., Torres-Ruiz, J., Gervilla, F. (eds.), Gurrent research in geology applied to ore deposits, Proceedings of the 2nd SGA Biennial Meeting: Granada, Spain, Universidad de Granada, 715-718.

Costa, F., Camprubí, A., Melgarejo, J.C., 1994, Aproximación geológica a las minas de fosfatos férrico-alumínicos de Gavà (Cataluña): Boletín Geológico y Minero 105, 18-25.

Daura,J., Sanz, M., García, N., Allué, E., Vaquero, M., Fierro, E., Carrión, J.S., López-García, J.M., Blain, H.A., Sánchez-Marco, A., Valls, C., Albert, R.M., Fornós, J.J., Julià, R., Fullola,J.M., Zilhão, J., 2013, Terraces of the Riera dels Canyars (Gavà, Barcelona): the landscape of Heinrich Stadial 4 north of the "Ebro frontier" and implications for modern human dispersal into Iberia: Quaternary Science Reviews, 60, 26-48.
Denayer, J., 2016, Iron ores from Southern Belgium: much more than hematite: Anthropologica et Praehistorica, 126, 39-49. Díaz-Acha, Y., Melgarejo, J.C., Bosch, J., Andreazini, A., Pastor, M., Pujol-Solà, N., Campeny, M., Torró, L., Villanova-deBenavent, C., Castillo-Oliver, M., Lehbib, S., Camprubí, A., Proenza, J.A., 2019, The Neolithic variscite mines of Gavà, Catalonia: criteria for mineral exploration and exploitation in the Prehistory: Boletín de la Sociedad Geológica Mexicana, 71(2), 295-319.

Diez, G., Rosell, J., 2013, La montgomeryita de les mines de Rocabruna, Bruguers, Gavà. Algunes consideracions sobre minerals de Bruguers: Infominer, 56, 56-57.

Elias, M., Chartier, C., Prévot, G., Garay, H., Vignaud, G., 2006, The colour of ochres explained by their composition: Materials Science and Engineering, 127B, 70-80.

Estrada, A., Bosch, J., 1997, Memòria de l'excavació arqueològica d'urgència al solar situat al C/ Roger de Flor / Avgda. Eramprunyà de Gavà, Baix Llobregat: Gavà, Spain, 3 Associats S.L., Unpublished Memory.

Ferrer-Modolell, A.E., 1991, Procesos hidrotermales asociados a la mineralización ferrífera de Celrá: Cadernos do Laboratorio Xeolóxico de Laxe, 16, 75-83.

García-López, S., Julivert, M., Soldevila, J., Truyols-Massoni, M., Zamarreño, I., 1990, Bioestratigrafía y facies de la sucesión carbonatada del Silúrico Superior y Devónico Inferior de Santa Creu d'Olorda (Cadenas Costero Catalanas): Acta Geologica Hispanica, 25, 141-168.

García-López, S., Rodríguez-Cañero, R., SanzLópez,J., Sarmiento, G., Valenzuela-Ríos, J.I., 1996, Conodontos y episodios carbonatados en el Silúrico de la Cadena Hercínica 
meridional y del Dominio Sahariano: Revista Española de Paleontología, extraordinary issue, $33-57$.

Guimerà, J., 1984, Paleogene evolution of deformation in the north-eastern Iberian peninsula: Geological Magazine, 121, 413-420.

Instituto Geológico y Minero de España (IGME), 1976a, Explicación del Mapa Geológico de España, a escala 1:50.000 (2 ${ }^{\text {a }}$ Serie). Hoja 420 (Hospitalet de Llobregat): Madrid, Spain, Instituto Geológico y Minero de España. Ministerio de Industria.

Instituto Geológico y Minero de España (IGME), 1976b, Explicación del Mapa Geológico de España, a escala 1:50.000 (2 ${ }^{\text {a }}$ Serie). Hoja $\mathrm{n}^{\circ} 448$ (Gavà): Madrid, Spain, Instituto Geológico y Minero de España. Ministerio de Industria.

Jové, F., 1981, Toponímia de Les Borges del Camp i del seu terme municipal, Reus: Reus, Catalonia, Associació d'Estudis Reusencs, $171 \mathrm{p}$

Julivert, M., Duran, H., 1990a, Paleozoic stratigraphy of the Central and Northern part of the Catalan Coastal Ranges (NE Spain): Acta Geologica Hispanica, 25, 3-12.

Julivert, M., Duran, H., 1990b, The Hercynian structure of the Catalonian Coastal Ranges (NE Spain): Acta Geologica Hispanica, 25, 13-21.

Julivert, M., Duran, H., Rickards, R.B., Chapman, A.J., 1985, Siluro-Devonian graptolite stratigraphy of the Catalan Coastal Ranges: Acta Geologica Hispanica, 20, 199-207.

Leal-Meca, M., Lillo-Ramos, J., 2009, Los yacimientos de hierro, alunita y jarosita de la zona de Riaza como posible origen del arsénico en las aguas subterráneas: Boletín Geológico y Minero, 120, 7-16.

Levato, G., 2016, Iron oxides prehistoric mines: an European overview: Anthropologica et Praehistorica, 126, 9-23.
Loucks, R.G., 1999, Paleocave carbonate reservoirs: origins, burial-depth modifications, spatial complexity, and reservoir implications: American Association of Petroleum Geologists Bulletin, 83, 1795-1834.

Maluquer, S., 1905, Minerals de ferro i manganès a Gavà: Butlletí de l'Institució Catalana d'Història Natural, 5, 1-8.

Mata-Perelló, J.M., 1990, Els minerals de Catalunya: Barcelona, Spain, Memòries de l'Institut d'Estudis Catalans, 13, 441 p.

Mata-Perelló, J.M., Montoriol-Pous, J., 1975, Nota referente a la bibliografía sobre los óxidos de Cataluña: Acta Geologica Hispanica, 3, 89-100.

Maureta, J., Thos, S., 1881, Descripción física, geológica y minera de la provincia de Barcelona: Madrid, Spain, Memorias Comisión Mapa Geológico de España, 487 p.

Melgarejo,J.C., Galí, S., Ayora, C., 1988, Tinticite: new structural and chemical data: Neues Jahrbuch für Mineralogie, Monatshefte, 446-453.

Melgarejo, J.C., Fontan, F., Alfonso, P., Camprubí, A., Costa, F., Salvany, M., Sáez, G., Arcas, A., 1997, Asociaciones minerales de rocas fosfatadas sedimentarias y sus derivados meteóricos y metamórficos, in Melgarejo, J.C. (ed.), Atlas de asociaciones minerales en lámina delgada: Barcelona, Spain, Edicions de la Universitat de Barcelona, 323-332.

Molinàs, R., 2007, Serra de les Ferreres, Mines 97, 98, 99, 100, 101 i 103. C/ Clara Campoamor amb Rambla Pompeu Fabra, Gavà (Baix Llobregat): Barcelona, Spain, Departament de Cultura i Mitjans de Comunicació, Generalitat de Catalunya, Biblioteca del Patrimoni Cultural, Direcció General del Patrimoni Cultural, Servei d'Arqueologia i Paleontologia, 59 p.

Morad, S., Al-Aasm, I.S., Longstaffe, F., Marfil, R., De Ros, L.F., Johansen, H., Marzo, M., 1995, Diagenesis of a mixed siliciclastic/evaporitic 
sequence of the Middle Muschelkalk (Middle Triassic), the Catalan Coastal Range, NE Spain: Sedimentology, 42, 749-768.

Morer, J., Rigo, A., 1999, Ferro i ferrers en el món ibèric. El poblat de les Guàrdies (El Vendrell): Barcelona, Spain, AUCAT, Autopistes de Catalunya S.A., Departament de Cultura de la Generalitat de Catalunya, 63 p.

Planas, E., Portolés, A., 1995, Castellar del Vallès. Recull Històric: Castellar del Vallès, Spain, Ajuntament de Castellar del Vallès, 223 p.

Postigo-Mijarra, J.M., Burjachs, F., GómezManzaneque, F., Morla, C., 2007, A palaeoecological interpretation of the lower-middle Pleistocene Cal Guardiola site (Terrassa, Barcelona, NE Spain) from the comparative study of wood and pollen samples: Review of Palaeobotany and Palynology, 146, 247-264.

Rius, J., Louer, D., Louer, M., Galí, S., Melgarejo, J.C., 2000, Structure solution from powder data of the phosphate hydrate tinticite: European Journal of Mineralogy, 12, 581-588.

Salas, R., 1987, El Malm i el Cretaci inferior entre el Massís de Garraf i la Serra d'Espadà. Anàlisi de conca: Barcelona, Spain, Universitat de Barcelona, Unpublished PhD Dissertation, 3 vols., $345 \mathrm{p}$.

Sanmartí, J., 2014, L'estat del coneixement sobre la cultura ibèrica a Catalunya: Butlletí de la Societat Catalana d'Estudis Històrics, 25, 227-260.

Sarabia, F.J., 1994, Aproximación teórica y metalográfica a la reducción de hierro en la Prehistoria partiendo del trabajo experimental: Trabajos de Prehistoria, 51, 95-109.

Sauder, L., Williams, S., 2002, A practical treatise on the smelting and smithing of bloomery iron: Historical Metallurgy, 36, 122-131.

Solé-Benet, A., Julià-Brugués, R., Ballbé-Llonch, E., 1988, Micromorfología y Mineralogía de un paleosuelo pleistoceno del Pla de Barcelona: Acta Geologica Hispanica, 23, 197-207.
Thelemann, M., Bebermeier, W., Hoelzmann, P., Lehnhardt, E., 2017, Bog iron ore as a resource for prehistoric iron production in Central Europe. A case study of the Widawa catchment area in eastern Silesia, Poland: Catena, 149, 474-490.

Torres-Ruiz, J., 1983, Genesis and Evolution of the Marquesado and Adjacent Iron Ore Deposits, Granada, Spain: Economic Geology, 78, 1657-1673.

Tritlla,J., 1987, Sobre la presencia de dufrenita en las minas de Bruguers (Prov. de Barcelona): Mineralogistes de Catalunya, 2, 208-209.

Tylecote, R.F., 1992, The history of metallurgy, II Edition: London, UK, The Institute of Materials, Maney Publishers, 205 p.

Villalba, M.J., 2002, Le gîte de variscite de Can Tintorer: Production, transformation, et circulation du minéral vert, in Guilaine, J. (ed.), Matériaux, productions, circulations du Néolithique à l'âge du bronze: Paris, France, Éditions Errance, 115-129.

Villalba, M.J., Alonso, M., 1984, Informe sobre les excavacions d'urgència realitzades en el jaciment arqueològic de Can Tintorer, Gavà (Baix Llobregat), 1982-1983: Barcelona, Spain, Servei d'Arqueologia, Generalitat de Catalunya, Unpublished Report.

Villalba, M.J., Bañolas, L., Arenas, J., Alonso, M., 1986, Les mines neolítiques de can Tintorer. Gavà. Excavacions 1978-1980: Barcelona, Spain, Departament de Cultura de la Generalitat de Catalunya, Excavacions Arqueològiques a Catalunya, 6, 203 p.

Villalba, M.J., Blasco, A., Edo, M., Bañolas, L., Arenas, J., 1989, Minería neolítica: Can Tintorer, una aportación fundamental: Revista de Arqueología, 96, 13-24.

Villalba, M.J., Bañolas, L., Arenas, J., 1990, Can Tintorer (Gavà, Catalunya): une exploitation néolithique de phosphates et silicates: Cahiers du Quaternaire, 17, 275-285.

Virgili, C., 1958, El Triásico de los Catalánides: Madrid, Spain, Boletín del Instituto Geológico y Minero de España, 69, 858 p. 